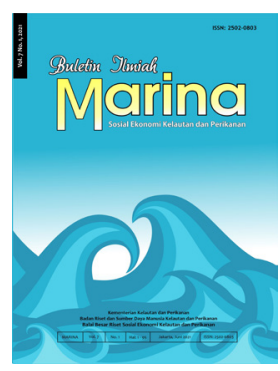

BULETIN ILMIAH MARINA

SOSIAL EKONOMI KELAUTAN DAN PERIKANAN

http://ejournal-balitbang.kkp.go.id/index.php/mra

p-ISSN: 2502-0803

e-ISSN: 2541-2930

Nomor Akreditasi: 10/E/KPT/2019

\title{
Strategi Penghidupan Masyarakat Pesisir di Giligenting Kabupaten Sumenep, Jawa Timur
}

\section{Livelihood Strategy of Giligenting Coastal Community in Sumenep Regency, East Java Province}

\author{
*Nyimas Nadya Izana dan Anik Susanti \\ Jurusan Sosiologi, Fakultas IImu Sosial dan IImu Politik, Universitas Brawijaya \\ JIn. Veteran Malang, Kecamatan Lowokwaru, Kota Malang, Jawa Timur, Indonesia \\ Diterima tanggal: 29 Januari 2020 Diterima setelah perbaikan: 15 April 2021 \\ Disetujui terbit: 30 Juni 2021
}

\begin{abstract}
ABSTRAK
Penelitian ini bertujuan untuk mengidentifikasi potensi lokal dan permasalahan ekonomi masyarakat pesisir Pulau Giligenting, Kabupaten Sumenep, serta menganalisis strategi penghidupan masyarakat pesisir yang dilakukan dalam menyelesaikan permasalahan ekonominya. Penelitian ini dilakukan pada bulan April-September tahun 2019. Metode penelitian yang digunakan dalam penelitian ini adalah deskriptif kualitatif dengan metode pengumpulan data melalui wawancara, observasi, dan studi literatur. Jenis informan dalam penelitian ini adalah perangkat desa, tokoh pemuda, dan masyarakat yang berprofesi sebagai nelayan dan petani, sedangkan data sekunder terdiri dari dokumen, seperti buku, jurnal, sumber dari arsip, dan dokumen resmi. Hasil penelitian menunjukkan bahwa problematika masyarakat Pulau Giligenting adalah minimnya penduduk yang berusia produktif, kurangnya air untuk pertanian, hingga keberadaan perusahaan migas yang mengganggu mata pencaharian karena mencemari ekosistem laut sekitar. Namun untuk bertahan dari permasalahan tersebut, mereka tidak melakukan diversifikasi mata pencaharian, akan tetapi justru mengambil langkah untuk migrasi. Masyarakat Pulau Giligenting secara sosio-historis memang telah memiliki kebiasaan bermigrasi ketika dihadapkan dengan masalah ekonomi. Hingga kini, kebiasaan tersebut masih dipercaya sebagai jalan keluar dari masalah ekonomi, walaupun daerah mereka saat ini mempunyai potensi pariwisata yang menjanjikan bagi keberlangsungan hidup masyarakat Pulau Giligenting.
\end{abstract}

Kata Kunci: masyarakat pesisir; Pulau Giligenting; potensi lokal; strategi penghidupan; Sumenep

\section{ABSTRACT}

This studyaimsto identify the potency of natural resources and the problems which wereeconomically encountered by Giligenting coastal community, and to analyze the livelihood strategies used to overcome their problems. The study was conducted in April until September 2019 with descriptive qualitative method. Data were collected through interview with selected informan, observation, and secondary data source. The informan of this study were village officials, youth leaders, fishers, and farmers, while secondary data were obtained from books, journals, sources from archives, and official documents. The result showed that Giligenting coastal community has been dealing with seasonal drought, contamination of mining activities and lack of human resources. Respond to their problems, Giligenting coastal community take strategies not only livelihood diversification but also migration to Jakarta City. The communities of Giligenting Island have a socio-historical habit to migrate as a believe to resolve their economic problems despite of the potential tourism area of Giligenting Island for the survival of its communities.

Keywords: coastal communities; Giligenting Island; local potency; livelihood strategies; Sumenep 


\section{PENDAHULUAN}

\section{Latar Belakang}

Indonesia sebagai negara kepulauan nyatanya belum mampu untuk mengangkat kesejahteraan masyarakat pesisir. Berdasarkan data Kementerian Kelautan dan Perikanan tahun 2015, jumlah kemiskinan di daerah pesisir mencapai $32,14 \%$ dari total jumlah penduduk miskin nasional (Sabarriman, 2017). Laporan terakhir BPS tahun 2015, angka kemiskinan masyarakat pesisir menunjukan penurunan, menjadi sekitar $25 \%$ atau sekitar 7,87 juta rumah tangga miskin di wilayah pesisir, tetapi angka ini masih tergolong tinggi karena di lain pihak, data Potensi Desa (PODES) pada tahun 2018 menunjukan bahwa dari 83.931 desa, sebanyak $15,32 \%$ merupakan desa pesisir tepi laut dan sekitar 21,82\% penduduknya mempunyai sumber penghasilan utama pada subsektor perikanan. Angka ini menjadi bukti bahwa pemerintah Indonesia masih acuh terhadap seperempat penduduk Indonesia yang menetap di daerah pesisir, padahal Albert Begen mengatakan bahwa hampir $35 \%$ pendapatan negara bersumber dari hasil laut (Scoones, 2009). Data BPS menyebutkan bahwa periode Januari-November 2016-2017, nilai ekspor produk perikanan naik hingga $8,12 \%$; dari US $\$ 3,78$ miliar pada tahun 2016 menjadi US\$4,09 miliar pada tahun 2017. Bahkan, hasil laut ini mampu berkontribusi sebesar $30 \%$ terhadap Gross Domestic Product (GDP). Ini merupakan angka yang sangat besar dan sangat disayangkan jika kegiatan ekspor hasil laut yang diselenggarakan oleh pemerintah masih belum berdampak signifikan terhadap kesejahteraan masyarakat pesisir.

Sebenarnya pemerintah telah menyusun beberapa program pemberdayaan untuk merespon isu kesejahteraan masyarakat pesisir, tetapi sayangnya belum dilaksanakan secara maksimal, seperti program pemberian kartu nelayan, dari total 8.077.719 rumah tangga perikanan, hanya ada 1.108.852 kartu nelayan yang disiapkan oleh negara; pemberian asuransi kepada nelayan, mandat Undang-Undang Nomor 7 Tahun 2016 tentang Perlindungan dan Pemberdayaan Nelayan, Pembudi daya Ikan, dan Petambak Garam, juga baru diberikan sekitar 143.600 asuransi kepada nelayan (Ambari, 2018). Laporan terbaru dari Kementerian Kelautan dan Perikanan (KKP) Republik Indonesia per Agustus tahun 2019 juga menunjukan bahwa hingga saat ini pemberian asuransi nelayan baru mencapai pada angka 1.152.177 nelayan (Susanto,
2019). Angka ini tentunya masih sangat jauh dari jumlah keseluruhan rumah tangga nelayan di Indonesia yang seharusnya ter-cover kebijakan tersebut.

Selain itu, permasalahan kultural pada kehidupan nelayan itu sendiri juga menjadi indikator penting yang ikut menentukan keberhasilan program pemberdayaan masyarakat pesisir. Gaya hidup yang tidak produktif dan tidak efisien, rendahnya tingkat pendidikan, ketergantungan pada tengkulak, serta rendahnya kompetensi penguasaan teknologi mesin-mesin perikanan menjadi permasalahan yang tidak pernah usai dan menghambat penuntasan kesejahteraan masyarakat pesisir (Zamzami, 2011). Oleh karena itu, untuk menuntaskan isu kesejahteraan masyarakat pesisir, diperlukan pengkajian dua sisi yang tidak terpisah dari sisi pemerintah dan masyarakat pesisir itu sendiri sehingga ada kesesuaian antara penyusunan pembangunan berhaluan kelautan dengan realitas yang terjadi di lapangan.

Masalah kemiskinan pada masyarakat nelayan sebagaimana yang dipaparkan di atas juga dijumpai pada masyarakat Giligenting. Pengamatan yang dilakukan pada bulan Juli 2019 memberikan gambaran kehidupan sehari-hari masyarakat Giligenting. Bentang alam di Pulau Giligenting membentuk aktivitas penduduknya dan memungkinkan munculnya beberapa mata pencaharian. Wilayah yang memiliki luas kurang lebih $30 \mathrm{~km}^{2}$ ini dikelilingi oleh laut sehingga penduduknya banyak bekerja di sektor perikanan, seperti memancing ikan dengan alat tradisional, membuat keramba, dan membudi daya rumput laut. Hasil tangkapan sebagian dijual di pasar lokal dan sisanya dikonsumsi oleh rumah tangga mereka.

Penduduk Giligenting terlihat mengolah ladangnya dan mengusahakan beberapa tanaman, seperti jagung, ketela pohon, dan kelapa. Hasil panen jagung dan ketela pohon ditujukan untuk konsumsi rumah tangga, sedangkan hasil kelapa diperjualbelikan atau diproduksi menjadi minuman dan gula merah. Kegiatan pertanian juga dilaksanakan bersamaan dengan pemeliharaan ternak sapi yang digembalakan di pekarangan belakang rumahnya. Selain kegiatan perikanan, pertanian, dan penggembalaan ternak, penduduk Giligenting juga menekuni usaha kecil-kecilan, seperti toko kelontong dan warung makan. Kegiatan pariwisata sebenarnya sudah mulai menggeliat, 
tetapi perkembangannya hanya terbatas di Desa Bringsang dengan destinasi andalan bernama Pantai Sembilan.

Potensialam yang terkelola secara tradisional dan berorientasi pada subsisten menyebabkan penduduk mengalami kehidupan yang stagnan. Keberadaan dua perusahaan minyak, Santos Offshore dan Husky-Cnooc Madura Ltd (HCML), di sekitar Pulau Giligenting tidak memberikan dampak ekonomi dan sosial yang signifikan kepada masyarakat. Pada saat musim kemarau, petani di Giligenting tidak bisa lagi mengelola lahannya karena tipe pertanian mereka termasuk pertanian ladang kering. Pengairan yang umum dilakukan di lahan padi sawah tidak mungkin diterapkan di Pulau Giligenting.

Paparan di atas mungkin dapat menuntun pada asumsi tentang kondisi masyarakat Giligenting yang menderita kemiskinan karena tidak maksimalnya pengelolaan potensi laut dan keterbatasan sumber daya lahan untuk pertanian. Sayangnya, jika tidak memahami kehidupan mereka secara seksama dan mendalam, fenomena kemiskinan tidak akan terungkap muasalnya. Fenomena yang nampak di permukaan adalah masyarakat Giligenting berupaya menempuh strategi penghidupan berdasarkan potensi alam dan modal yang mereka miliki. Hal menarik yang ditawarkan oleh penelitian ini adalah penyajian upaya masyarakat Giligenting dalam memobilisasi potensi alam dan struktur sosial yang dibalut dalam strategi penghidupan masyarakat pesisir.

Terdapat beberapa penelitian terdahulu yang membahas strategi nafkah atau strategi bertahan hidup. Pertama, Karlita dan Pandjaitan (2017) menyatakan bahwa strategi bertahan hidup yang dilakukan oleh perempuan di daerah pesisir Dusun Muara, Desa Muara, Kabupaten Tangerang Banten adalah strategi bertahan hidup ekonomi dan sosial. Pada strategi bertahan hidup ekonomi, para perempuan di daerah tersebut mengikuti simpan pinjam, mengikuti paket hari raya, berinvestasi, melakukan berbagai pekerjaan, berbagi bahan makanan, dan berbagi aliran listrik. Strategi bertahan hidup sosial dilakukan dengan mengikuti arisan dan pinjaman. Kedua, hasil penelitian Widodo (2011) menyebutkan bahwa strategi nafkah rumah tangga nelayan miskin terdiri atas strategi ekonomi dan sosial. Strategi ekonomi dilakukan dengan cara melakukan pola nafkah ganda, yaitu memanfaatkan tenaga kerja rumah tangga dan migrasi, sedangkan strategi sosial dilakukan dengan memanfaatkan ikatan kekerabatan yang ada. Kedua penelitian ini belum membahas mengenai bagaimana strategi masyarakat Pulau Giligenting yang letaknya jauh dari Ibu Kota Sumenep, sekitar 21,5 kilometer. Oleh karena itu, artikel ini memiliki tiga tujuan utama, pertama, mengidentifikasi potensi lokal yang dapat dimaksimalkan oleh masyarakat Pulau Giligenting untuk meningkatkan kesejahteraannya; kedua, mengidentifkasi permasalahan yang dihadapi oleh masyarakat Pulau Giligenting; ketiga, menganalisis strategi penghidupan masyarakat Pulau Giligenting dalam menghadapi permasalahan ekonominya.

Untuk mencapai tiga tujuan tersebut, artikel ini memegang asumsi bahwa manusia mempertahankan hidupnya sesuai dengan keadaan yang ada di sekitarnya dan tetap memperhatikan sistem nilai budaya yang berlaku, yaitu struktur sosial. Oleh karena itu, Scoones (1998) mengatakan bahwa kerangka kerja pada sistem penghidupan pedesaan yang berkelanjutan memiliki sejumlah elemen dasar. Pertanyaan kunci yang harus ditanyakan dalam analisis penghidupan berkelanjutan adalah beberapa konteks tertentu (mengatur kebijakan, politik, sejarah, agroekologi, dan kondisi sosial ekonomi) yang dikombinasikan dari sumber livelihood (berbagai jenis "modal") yang menghasilkan kemampuan untuk mengikuti kombinasi pada strategi livelihood (intensifikasi/ ekstensifikasi, diversifikasi livelihood, dan migrasi) dengan hasil dari ketertarikan di dalam kerangka kerja tersebut adalah proses kelembagaan (embedded dalam matriks kelembagaan formal dan informal) yang memediasi kemampuan untuk melaksanakan strategi tersebut dan mencapai atau tidak hasil seperti itu.

Perspektif livelihood dibangun melalui sebuah pandangan tentang bagaimana orang yang berbeda di tempat yang berbeda dapat hidup. Berbagai definisi ditawarkan dalam literatur, termasuk misalnya, "sarana untuk mencari nafkah" (Chambers, 1995) atau "kombinasi sumber daya yang digunakan dan kegiatan yang dilakukan untuk hidup". Sebuah analisis deskriptif juga menggambarkan jaringan kegiatan dan interaksi kompleks yang menekankan keragaman cara orang memenuhi hidupnya. Strategimatapencaharianjuga dapat dipahami sebagai sarana untuk mengatasi gangguan eksternal dan mempertahankan kemampuan mata pencaharian (Wright et al., 2016). Sejak 1990-an, analisis mata pencaharian ini dominan digunakan dalam pendekatan untuk memahami bagaimana penduduk pedesaan 
mencari nafkah. Dalam beberapa dekade terakhir, beberapa lembaga, seperti FAO, UNDP, DFID, dan lain-lain, serta para peneliti telah mengembangkan kerangka kerja untuk menganalisis keberlanjutan mata pencaharian. Sebagian besar kerangka kerja ini serupa, perbedaannya terlihat pada perubahan terukur dalam berbagai faktor yang berkontribusi terhadap mata pencaharian: modal, proses kelembagaan, dan organisasi struktur, kerentanan mata pencaharian, strategi mata pencaharian, dan hasil (Carloni \& Crowley, 2005; Fang et al., 2014).

Kerangka mata pencaharian Scoones (Scoones, 1998) menunjukkan bahwa terdapat tiga kelompok besar livelihood strategy yang harus diidentifikasi. Tiga elemen tersebut adalah intensifikasi/ekstensifikasi pertanian, diversifikasi mata pencaharian, dan migrasi. Secara umum, ini mencakup berbagai pilihan terbuka untuk masyarakat perdesaan dalam mendapatkan lebih banyak mata pencaharian dari pertanian (termasuk pemeliharaan ternak, nelayan, dan kehutanan), seperti melalui proses intensifikasi (lebih banyak output per unit area melalui investasi modal atau peningkatan input tenaga kerja) atau ekstensifikasi (lebih banyak lahan untuk budi daya), diversifikasi ke berbagai kegiatan yang menghasilkan pendapatan di luar pertanian, bahkan pindah dan mencari mata pencaharian, baik sementara maupun permanen ke tempat lain. Selain itu, dapat juga dilakukan dengan kombinasi strategi bersama yang mungkin dapat dilakukan, yaitu (1) rekayasa sumber nafkah pertanian dengan melakukan intensifikasi atau ekstensifikasi pertanian. Intensifikasi pertanian berarti menambahkan input eksternal, yaitu teknologi dan tenaga kerja, sedangkan ekstensifikasi pertanian berarti memperluas lahan garapan; (2) keanekaragaman pola nafkah dengan cara mencari pekerjaan lain selain pertanian untuk menambah pendapatan, atau dengan mengerahkan tenaga kerja keluarga (ayah, ibu, dan anak) untuk ikut bekerja — selain pertanian- dan memperoleh pendapatan; serta (3) migrasi, merupakan usaha yang dilakukan dengan melakukan mobilitas ke daerah lain di luar desanya, baik secara permanen maupun sirkuler untuk memperoleh pendapatan (Scoones, 1998).

Kemampuan dalam strategi livelihood yang berbeda tergantung pada materi dasar dan social, tangible, dan intangible asset yang dimiliki setiap orang. Berdasarkan Departemen for International Development (1999), terdapat lima livelihood assets, di antaranya human capital, natural capital, financial capital, social capital, dan physical capital.

\section{Berikut penjelasannya:}

1. Modal alam, yaitu ketersediaan sumber daya alam (tanah, air, udara, sumber daya genetik, dan lain-lain) serta layanan lingkungan (siklus hidrologi, pollution sinks, dan lain-lain) yang sumber dayanya mengalir dan berguna untuk livelihood.

2. Modal ekonomi atau finansial, yaitu modal dasar (cash, kredit, debit, dan aset ekonomi yang lain, termasuk infrastruktur dasar serta peralatan dan teknologi produksi) yang penting untuk strategi livelihood.

3. Modal manusia, yaitu skill, pengetahuan, kemampuan untuk bekerja dan kesehatan yang baik serta kemampuan fisik yang penting untuk strategi livelihood.

4. Modal sosial, yaitu sumber daya sosial (jaringan, hubungan sosial, afiliasi, dan asosiasi) yang menggambarkan orang ketika melakukan strategi livelihood dan membutuhkan tindakan kolektif.

5. Modal fisik, terdiri dari infrastruktur dasar dan barang produksi yang dibutuhkan untuk menunjang mata pencaharian. Prasarana terdiri dari perubahan lingkungan fisik yang lebih produktif untuk membantu orang memenuhi kebutuhan dasar mereka. Barang produsen adalah alat dan perlengkapan yang digunakan seseorang agar lebih produktif.

Bagi Scoones (Scoones, 2009), langkah kunci dalam proses analisis kerangka di atas adalah mengidentifikasi sumber mata pencaharian (atau kombinasi modal) yang diperlukan untuk berbagai kombinasi livelihood strategy, misalnya, keberhasilan intensifikasi pertanian dapat menggabungkan akses modal alam (misalnyatanah, air, dan lain-lain) dengan modal ekonomi (misalnya teknologi, kredit, dan lain-lain), sedangkan dalam situasi lain, modal sosial (misalnya jaringan sosial yang terkait dengan kekeringan atau pengaturan pembagian kerja) mungkin juga lebih signifikan untuk dikombinasikan (Scoones, 2009). Oleh karena itu, penting untuk memahami dalam konteks yang dinamis dan historis, bagaimana sumber daya mata pencaharian yang berbeda dapat diurutkan dan digabungkan dalam menganalisis strategi penghidupan. Dengan menggunakan aset modal yang tersedia, orang akan terlibat dalam berbagai strategi mata pencaharian untuk mencapai tujuan mata pencaharian. Oleh karena itu, "strategi mata pencaharian" adalah berbagai kombinasi kegiatan 
dan pilihan yang dibuat orang untuk mencapai tujuan mata pencaharian mereka (Carloni \& Crowley, 2005). Kegiatan mata pencaharian ini terikat pada modal mata pencaharian karena mereka menentukan kemungkinan yang dapat terjadi pada rumah tangga pedesaan untuk mencapai tujuan yang terkait dengan pendapatan, keselamatan, dan kesejahteraan (van den Berg, 2010).

Strategi mata pencaharian nelayan memerlukan analisis yang berbeda karena mayoritas nelayan sering kali berada di bawah tingkat sosial ekonomi terendah di masyarakat. Hal ini disebabkan kurangnya organisasi, aset, fleksibilitas, dan tingkat kerentanan ekonomi yang tinggi pada kehidupan pesisir sehingga membuat nelayan memiliki modal lebih sedikit dan tidak mempunyai banyak opsi mata pencaharian lainnya. Banyak nelayan mempraktikkan penangkapan ikan sebagai mata pencaharian pilihan karena pengalaman mereka yang luas dalam perdagangan, keahlian biologis, dan kecintaan mereka pada kegiatan memancing. Nelayan hanya mempraktikkan spesialisasi tingkat rendah dan hanya mengandalkan penangkapan ikan sebagai mata pencaharian mereka (Giesbrecht, 2011; van Holt, 2012).

Di lain pihak, ketergantungan nelayan pada lingkungannya sangat mempengaruhi ekonominya. Perubahan lanskap dan input nutrisi terkait sistem pesisir secara langsung mempengaruhi komposisi komunitas laut yang mempengaruhi hasil tangkapan mereka. Sering kali perikanan dikelola berdasarkan faktor-faktor yang dianggap menentukan keberhasilan, padahal pada kenyataannya faktor-faktor ini mungkin dapat atau tidak dapat mendorong keberhasilan. Faktorfaktor yang mempengaruhi keberhasilan nelayan, baik upaya tangkapan per unit, tangkapan total, harga yang dibayarkan per $\mathrm{kg}$, atau laba, dapat berkontribusi pada identifikasi strategi yang dapat membantu nelayan dalam merespons perubahan (van Holt, 2012). Oleh karenaitu, beberapa penelitian terbaru berusaha menambahkan faktor-faktor yang menentukan strategi mata pencaharian. Faktorfaktor ini termasuk perlindungan keanekaragaman hayati (Salafsky \& Wollenberg, 2000), kesuburan tanah (Tittonell et al., 2010), pariwisata (Giesbrecht, 2011; Mbaiwa, 2011), tanaman, kehutanan, dan produk ternak (Zenteno et al., 2013), serta modal alam (Fang et al., 2014). Berdasarkan hal tersebut, analisis strategi penghidupan nelayan dapat juga mengarah pada pendekatan faktor perubahan lingkungan yang secara tidak sengaja membuat nelayan lebih berisiko, sehingga keahlian atau teknologi tidak lagi menguntungkan nelayan.

\section{Pendekatan IImiah}

Secara spesifik, penelitian ini dilakukan di Pulau Giligenting, terutama Desa Aenganyar, Desa Galis, Desa Bringsang, dan Desa Gedugan, Kabupaten Sumenep pada bulan April-September 2019. Keempat desa ini dipilih karena terkenal sebagai pusat Kecamatan Giligenting yang sekaligus merupakan desa yang terletak di Pulau Giligenting. Metode penelitian yang digunakan dalam penelitian ini ialah deskriptif kualitatif. Terdapat dua jenis data yang digunakan dalam penelitian ini, yaitu data primer dan sekunder. Data primer adalah data yang diambil dengan menggunakan teknik observasi (pengamatan) dan interview (wawancara). Penentuan informan yang digali datanya sebagai data primer menggunakan teknik purposive sampling, yaitu teknik menentukan informan sesuai kriteria yang telah ditentukan sebelumnya oleh peneliti. Informan yang diwawancarai oleh peneliti adalah perangkat desa, tokoh pemuda, dan masyarakat yang berprofesi sebagai nelayan dan petani. Jumlah informan sebanyak dua belas informan. Data sekunder diambil dari beberapa dokumen (buku, jurnal, sumber dari arsip, dan dokumen resmi). Setelah seluruh data terkumpul, peneliti melakukan analisis data. Teknik analisis data yang dilakukan adalah analisis data kualitatif. Analisis data kualitatif adalah proses mengorganisasikan dan mengurutkan data yang berupa kata dalam pola, kategori, dan satuan uraian dasar sehingga dapat ditemukan tema yang dapat menjawab hipotesis kerja seperti yang disarankan oleh data (Maloeng, 2018). Data kualitatif berupa data primer maupun sekunder diolah menggunakan tiga tahap kegiatan analisis, yaitu reduksi, penyajian data, dan penarikan kesimpulan. Pada penelitian ini, reduksi data dilakukan dengan cara menggolongkan hasil dari transkrip wawancara sehingga peneliti mengetahui mana yang akan digunakan untuk mendeskripsikan potensi desa yang ada di Giligenting dan mana yang digunakan untuk menganalisis strategi penghidupan masyarakat Giligenting. Data yang sudah direduksi akan disajikan dalam bentuk deskripsi dan diharapkan dapat menjawab perumusan masalah yang telah ditetapkan, kemudian ditarik kesimpulan dari data primer dan sekunder yang telah direduksi. Setelah mereduksi, peneliti mendeskripsikan secara detail untuk menjawab rumusan masalah 
mengenai gambaran potensi desa di Giligenting dan menjelaskan untuk menganalisis strategi penghidupan masyarakat setempat.

\section{POTENSI KEPULAUAN DAN DINAMIKA MASYARAKAT PULAU GILIGENTING}

Berdasarkan Badan Pusat Statistik [BPS] Kabupaten Sumenep (2018)-Kecamatan Giligenting Dalam Angka 2018- terdapat delapan desa, yaitu Desa Galis, Desa Gedugan, Desa Birngsang, Desa Aenganyar, Desa Lombang, Desa Jate, Desa Banburu, dan Desa Banmalang. Apabila dilihat melalui citra satelit, kedelapan desa ini terletak di dua wilayah kepulauan, yaitu Pulau Giligenting dan Pulau Gili Raja. Penelitian ini difokuskan di Pulau Giligenting karena letak pulau tersebut menjadi satu dengan pusat pemerintahan Kecamatan Giligenting. Pulau Giligenting terdiri atas empat desa, yaitu Desa Galis, Desa Gedugan, Desa Bringsang, dan Desa Aenganyar. Keempat desa ini merupakan desa pantai dengan kondisi jenis tanahnya adalah tanah kering. Menurut publikasi BPS Kabupaten Sumenep (2017)Kecamatan Giligenting Dalam Angka Tahun 2017-, kebanyakan penggunaan lahan untuk ladang dan sisanya untuk tambak/kolam. Desa Galis memiliki 424,24 ha untuk ladang dan 0,92 ha untuk tambak/ kolam; Desa Gedugan terdapat 351,00 ha untuk ladang dan 4,32 ha untuk tambak/kolam; Desa Bringsang 218,00 ha untuk ladang dan 0,14 untuk tambak/kolam; serta Desa Aenganyar terdapat 158,49 ha untuk ladang.

Apabila ditilik lebih lanjut berdasarkan hasil penelitian dan data BPS Kabupaten Sumenep (2018)-Kecamatan Giligenting Dalam Angka 2018-, Desa Aenganyar memiliki luas wilayah $3,39 \mathrm{~km}^{2}$ dan dikenal sebagai pusat pulau karena tersedianya pelayanan dan fasilitas publik yang memadai, yaitu puskesmas, pasar, kantor kecamatan, PLN, KUA, pendidikan SD-MA dan Bank Perkreditan Rakyat (BPR). Desa Galis memiliki luas wilayah $6,60 \mathrm{~km}^{2}$ dan merupakan desa yang paling luas dibandingkan dengan Desa Gedugan, Desa Bringsang, dan Desa Aenganyar. Pertanian di desa tersebut hanya mengandalkan musim hujan sehingga mereka hanya melakukan panen jagung satu tahun sekali. Terdapat ruang baca di salah satu rumah warga yang diperuntukkan untuk anak-anak sampai remaja dan terdapat potensi wisata berupa Pantai Sorok yang dikembangkan oleh pemerintah desa. Desa Gedugan memiliki luas wilayah $5,26 \mathrm{~km}^{2}$. Desa Gedugan dikelilingi oleh pantai, dari Pantai Pasir Putih sampai dengan
Pantai Kahuripan. Kondisi geografis seperti itu membuat kebanyakan warganya memiliki mata pencaharian sebagai nelayan sehingga memiliki kelompok nelayan. Kelompok nelayan di Desa Gedugan setiap tahunnya selalu melakukan ritual atau acara "petik laut". Acara ini diselenggarakan tiga hari berturut-turut, dengan mendatangkan ustaz dan mengadakan slametan. Ritual ini merupakan aktualisasi dari rasa syukur mereka. Saat ini, Desa Bringsang telah menjadi inspirator desa-desa tetangga, seperti Galis, Gedugan, dan Aenganyar. Meskipun desa ini baru berkembang dan dikenal akan perkembangan pantai sembilan-nya, berdasarkan informasi dari situs web Kabupaten Sumenep, Desa Bringsang mampu meraih prestasi sebagai wisata pantai terbaik nomor dua di Jawa Timur pada tahun 2018.

Terdapat perbedaan karakteristik antara masyarakatagraris dan masyarakat pesisir. Menurut Satria (2015), secara sosiologis karakteristik masyarakat pesisir berbeda dengan karakteristik masyarakat agraris. Hal ini dikarenakan adanya perbedaan karaketristik lingkungan dan sumber daya yang dihadapi. Masyarakat agraris yang direpresentasikan oleh kaum tani menghadapi sumber daya yang terkontrol, yakni pengelolaan lahan untuk produksi komoditas dengan hasil yang relatif dapat diprediksi, sedangkan nelayan menghadapi sumber daya yang hingga saat ini masih bersifat akses terbuka (open access). Karakteristik sumber daya seperti ini mengakibatkan nelayan harus berpindah-pindah untuk memperoleh hasil yang maksimal, sehingga elemen risiko masyarakat pesisir sangat tinggi (Satria, 2015). Selain itu, tidak sedikit nelayan yang juga merangkap sebagai petani, tetapi perlu ditunjang oleh kondisi ekosistem yang memungkinkan, seperti ketersediaan area lahan persawahan di sekitar pantai. Terdapat musim-musim tertentu bagi nelayan untuk turun ke sawah, sementara pada musim lainnya mereka kembali melaut. Rangkapan pekerjaan tersebut merupakan bagian dari pola adaptasi masyarakat pesisir terhadap kondisi ekologi yang mereka hadapi.

Hal ini juga ditemukan pada masyarakat Giligenting, bahwa mereka melakukan strategi nafkah untuk bertahan hidup. Salah satu bentuk strategi mereka adalah migrasi. Masyarakat Giligenting lebih sering memilih untuk pergi merantau ke luar Pulau Madura dan anak-anak mereka dititipkan kepada orang tua yang masih menetap di Giligenting atau ditempatkan di pondok pesantren agar pendidikan agama tidak luntur. Hal 
ini didukung dengan dikenalnya Madura sebagai pulau santri karena banyaknya jumlah pesantren, mulai dari Kabupaten Bangkalan hingga Sumenep. Bahkan, di pulau-pulau kecil juga banyak terdapat pondok pesantren karena masyarakat Madura hampir 100\% beragama Islam. Salah satu faktor yang menopang kuatnya agama Islam di Madura adalah pondok pesantren (Syamsuddin, 2019). Berdasarkan publikasi, angka datang dan pergi di Kecamatan Giligenting dari tahun 2017-2018 juga masih menunjukkan angka ketimpangan. Tabel 1 menunjukkan jumlah penduduk datang dan pergi.

Tabel 1 menunjukan bahwa angka ketimpangan penduduk datang dan pergi masih menunjukkan margin yang besar. Angka penduduk pergi tidak sebanding dengan angka penduduk datang, hal ini mengisyaratkan bahwa banyak penduduk Giligenting yang pada akhirnya memutuskan untuk menetap di daerah migrasi. Selain itu, menurut Sekretaris Desa Aenganyar, data tersebut adalah data yang berhasil dihimpun oleh pihak kecamatan. Kenyataan di lapangan menunjukkan masih banyaknya penduduk migrasi yang belum terdata sehingga data tersebut adalah data yang dilaporkan oleh masing-masing desa. Bahkan, Sekretaris Desa Aenganyar hampir memastikan bahwa angka migrasi di Pulau Giligenting mencapai angka 90\% penduduk, sedangkan $10 \%$ sisanya adalah orang tua perantau yang tidak ikut bermigrasi (hasil wawancara dengan Sekretaris Desa Aenganyar pada tanggal 24 Juli 2019).

\section{PERMASALAHAN YANG DIHADAPI MASYARAKAT PULAU GILIGENTING}

Hasil penelitian menunjukan bahwa problematika yang dihadapi pada keempat desa yang menjadi lokasi penelitian secara garis besar adalah sama. Pertama, banyaknya penduduk usia produktif lebih memilih meninggalkan daerah asal untuk mencari mata pencaharian. Hal ini terjadi karena masih tingginya mindset bahwa bekerja di kota-kota besar lebih menguntungkan daripada di daerah asal. Akibatnya, Pulau Giligenting kini lebih dominan dihuni oleh penduduk usia nonproduktif yang hanya hidup dengan mengandalkan uang kiriman dari keluarganya yang bermigrasi. Bahkan, hasil penelitian menunjukan bahwa dalam satu bulan data pengiriman uang di kantor pos, mencatat hampir 2 miliar rupiah uang dikirimkan ke Giligenting. Hal ini menjadi bukti bahwa banyaknya masyarakat Giligenting yang melakukan migrasi untuk menambah penghasilan. Hal ini diperkuat dengan pernyataan salah satu informan (perangkat Desa Gelis) yang menjelaskan jumlah uang yang berputar di Giligenting, sebagai berikut:

$$
\begin{aligned}
& \text { “Orang yang kerja merantau ketika pulang } \\
& \text { ke Giligenting bisa menghabiskan uang } \\
& \text { sebesar } 70 \text { juta rupiah per tiga bulan. Cara } \\
& \text { menggunakan uang sederhananya begini, } \\
& \text { kalau bulan Sya'ban, Ramadhan sama } \\
& \text { Syawal, harga ikan di sini naik harganya, } \\
& \text { jadi uangnya dibelanjakan buat itu. Jadi } \\
& \text { orang-orang di sini pas bulan-bulan } \\
& \text { tersebut banyak yang puasa buat beli } \\
& \text { ikan dulu, istilahnya ngalah dulu karena } \\
& \text { harganya naik bisa tiga kali lipat." }
\end{aligned}
$$

(Hasil wawancara pada tanggal 23 Juli 2019)

Kota yang paling sering menjadi tujuan adalah kota besar seperti Jakarta, Semarang, Tegal, dan Bandung. Besarnya penghasilan yang mereka terima dari kota-kota tersebut semakin memperkuat mindset keberuntungan di kota-kota besar. Bahkan, mindset migrasi ini sampai memunculkan anggapan yang mengatakan bahwa "lebih baik memelihara cucu daripada memelihara sapi”, karena jika mengasuh cucu maka kehidupannya dapat bergantung dengan kiriman. Memang sejak lama remitansi telah dianggap sebagai pusat penghidupan dan perubahan dalam perekonomian di suatu pulau karena selalu dianggap mampu meningkatkan perekonomian secara cepat (Connell \& Conway, 2000). Hal ini

Tabel 1. Jumlah Penduduk Datang dan Pergi di Kecamatan Giligenting Tahun 2017-2018.

\begin{tabular}{lcccc}
\hline \multirow{2}{*}{ Desa } & \multicolumn{2}{c}{ Datang } & \multicolumn{2}{c}{ Pergi } \\
\cline { 2 - 5 } & $\mathbf{2 0 1 7}$ & $\mathbf{2 0 1 8}$ & $\mathbf{2 0 1 7}$ & $\mathbf{2 0 1 8}$ \\
\hline Galis & - & 5 & 29 & 48 \\
Bendungan & - & 3 & 20 & 18 \\
Bringsang & - & 2 & 49 & 22 \\
Aenganyar & 5 & 5 & 42 & 25 \\
\hline
\end{tabular}

Sumber: BPS Kabupaten Sumenep, 2019 
diperkuat dengan pernyataan salah satu informan yang bermata pencaharian sebagai petani.

\section{"Pada saat musim kemarau, petani/warga sini menunggu kiriman dari keluarganya yang bekerja di Jakarta. Bisa dilihat di kantor pos kiriman per bulannya ke sini berapa, belum yang tidak lewat kantor pos. Sampai memunculkan mindset 'lebih baik memelihara cucu daripada memelihara sapi' karena kenapa, kalau mengasuh cucu/anak orang yang merantau akan mendapat kiriman per bulan daripada berternak."}

(Hasil wawancara pada tanggal 29 Juli 2019)

Problem migrasi ini juga semakin meluas ketika masyarakat Pulau Giligenting hanya memanfaatkan uang remitansi untuk kebutuhan dasar, seperti rumah, pakaian, dan makanan, tanpa mempertimbangkan investasi jangka panjang. Kecenderungan ini sangat terlihat terutama di Desa Galis, persaingan pembangunan rumah antar masyarakat sangat terlihat jelas. Penggunaan uang remitansi memang dapat membantu kenaikan status sosial-ekonomi (Ahlburg, 1991; Marshal, 1984). Di sisi lain, hal ini diklaim akan merugikan prospek jangka panjang bagi masyarakat karena mereka tidak mengubah atau meremajakan sektor ekonomi pedesaan, mereka justru mengabadikan keterbatasan kemiskinan struktural mereka (Mandle, 1996; Rubenstein, 1983). Selain itu, dalam hal hubungan sosial, konsekuensi negatif dari pengiriman uang dapat melemahkan hubungan sosial, peran gender keluarga, dan pengaturan tenaga kerja, serta pelebaran stratifikasi sosial berdasarkan sumber kekayaan eksternal, daripada diferensiasi kelayakan komunal (Branda-Shute \& Brana-Shute, 1982).

Permasalahan berikutnya adalah masalah air di sektor pertanian. Jenis kontur tanah yang tandus mengakibatkan masyarakat Giligenting harus menggunakan sistem pengairan sumur dan tadah hujan. Sayangnya, hal ini tetap menjadi masalah karena kurangnya curah hujan dan tingkat evapotranspiration yang tinggi di daerah pulau membuat masalah air sulit diselesaikan (Papadimitriou et al., 2019), padahal, jaminan kualitas air yang tepat untuk irigasi juga penting untuk daya saing ekonomi dan mendukung kualitas produk pertanian (Attard \& Azzopardi, 2005). Hal ini menjadi penting karena beberapa studi menunjukan bahwa budi daya pertanian mampu meningkatkan perekonomian masyarakat pulau setidaknya 3-4\% dari penghasilan seharihari (Robert et al., 2015).

Selain itu, para petani juga mengalami kekurangan pupuk dan obat tanaman. Akibatnya, mereka sering mengalami kerugian pada saat pascapanen. Segala upaya telah dilakukan oleh penyuluh lapang dari Dinas Pertanian, Bapak Budi, tetapi petani masih mengeluh sehingga kondisi tanaman saat panen tidak berisi, akibatnya sulit untuk dijual ke pasar. Oleh karena itu, masyarakat pulau umumnya memanfaatkan hasil pertanian hanya dalam hal kuantitas, sementara kualitasnya memang selalu buruk karena gangguan garam dan polusi nitrat (Aparicio et al., 2019; Viola et al., 2014). Komoditas tanaman lain yang mayoritas ditanam oleh petani Pulau Giligenting adalah jagung dan pepaya sehingga aktivitas tanam hanya dilakukan di musim hujan saja, artinya masyarakat Pulau Giligenting hanya dapat menikmati hasil panen setahun sekali sehingga sektor pertanian hanya dimanfaatkan sebagai penghasilan tambahan atau bahkan hanya untuk dikonsumsi sendiri.

Masalah selanjutnya yang tidak kalah penting adalah keberadaan perusahaan-perusahaan migas di area perairan Pulau Giligenting. Bagaimanapun, eksplorasi perusahaan-perusahaan tersebut sangat mempengaruhi ekosistem laut di sekitar Pulau Giligenting karena pencemaran yang dihasilkan oleh penambangan minyak di laut lepas selalu berdampak signifikan pada degradasi keanekaragaman hayati laut (Putri et al., 2016). Sebuah studi di sekitar Pulau Giligenting juga telah membuktikan bahwa keanekaragaman hayati di Pulau Gelinting mulai menunjukkan penurunan kualitas (Islam et al., 2019). Kondisi inilah yang kemudian berdampak besar pada rantai ekonomi masyarakat Pulau Giligenting, karena mayoritas masyarakat Pulau Giligenting menggantungkan kehidupannya pada hasil laut.

Pulau Giligenting sendiri memang tergolong sebagai area yang dijuluki sebagai area Pulau Segitiga Emas. Pulau Segitiga Emas ini terdiri atas Pulau Gili lyang, Gili Labak, dan Giligenting yang letaknya saling berdekatan dan membentuk garis segitiga. Penamaan tersebut jika ditelaah dalam perspektif ekonomi lokal bertujuan untuk mengangkat ikon-ikon yang dimiliki oleh tiga pulau tersebut. Hal ini dikarenakan selain adanya potensi pantai yang indah, tiga pulau itu dikenal sebagai pulau yang mempunyai aset bernilai jangka panjang, salah satunya sebagai area yang mempunyai 
titik migas (Blok Maleo). Bahkan, besarnya penghasilan minyak yang mampu dihasilkan dari Blok Maleo mampu menimbulkan konflik antara pemerintah pusat dan pemerintah lokal. Konflik ini berkaitan dengan perebutan dana bagi hasil antara perusahaan dan pemerintah yang mampu mencapai angka 100 miliar rupiah per tahun (Huda \& Yunas, 2017). Walaupun demikian, pemerintah setempat harus tetap mempertimbangkan kelangsungan rantai ekonomi masyarakat sebelum memberikan izin penambangan kepada sebuah perusahaan. Jika tidak, hal ini dapat berdampak pada kelangsungan kehidupan lokal masyarakat Pulau Giligenting.

\section{STRATEGI PENGHIDUPAN MASYARAKAT PESISIR DI PULAU GILIGENTING}

\section{Aspek Sosio-Historis yang Mempengaruhi Strategi Penghidupan Masyarakat Pulau Giligenting}

Seperti yang dinyatakan oleh Scoones (1998, 2009) bahwa strategi penghidupan masyarakat pedesaan dapat dilakukan dengan menjabarkan konteks daerah tersebut. Secara garis besar, cara strategi bertahan hidup masyarakat Pulau Giligenting adalah selalu menyesuaikan dengan konteks lingkungan sekitar. Berdasarkan hasil penelitian Purba (2016), sekitar tahun 1950, masyarakat Giligenting mempunyai hasil pertanian gula siwalan dan jagung. Pada masa itu, hasil pertaniannya ditukar ke Situbondo dan Bondowoso dengan menerapkan model transaksi barter. Mereka menggunakan perahu layar, berangkat sore hari dan tiba di lokasi sasaran sekitar dua sampai dengan tiga hari. Pada saat balik, warga biasanya membawa padi, gula pasir, dan sayuran. Pada tahun itu, masyarakat juga masih menerapkan pola melaut dengan menggunaan sistem tradisional atau sistem kearifan lokal nelayan, yaitu dengan menyesuaikan tanggal dan kondisi musim. Pada tahun 1960-1980, masyarakat Giligenting menerapkan strategi bertahan hidup dengan pola aktivitas pelayaran kayu di lintas provinsi. Pada masa itu, pemilik kapal merupakan kalangan dari kelas atas, mereka sukses bahkan pernah mempunyai lahan yang berada di Sumatra dan Kalimantan. Satu kali pelayaran membutuhan waktu 2-3 bulan, sampai akhirnya para awak kapal mendapatkan upah sebesar 3-4 juta rupiah sesuai dengan posisi awak kapal, misalnya berperan sebagai teknisi mesin, koki masak, kapten, dan lainnya. Pada masa itu, masyarakat Giligenting mengalami kepesatan pertumbuhan ekonomi keluarga. Bentuk rumah-rumah warga mulai meniru atau imitasi terhadap bentuk rumah yang berada di daratan. Namun sayangnya, aktivitas pelayaran hanya mampu beroperasi selama 20 tahun lamanya. Setelah rezim orde baru terdapat peraturan yang melarang illegal logging sehingga lambat laun banyak pemilik kapal menjual kapalnya di beberapa wilayah, harga satu kapal ada yang sampai 500 juta bahkan 1 miliar rupiah.

Pada tahun 1985-1990, masyarakat Giligenting mengalami musim paceklik dari mata pencaharian utama mereka (Purba, 2016). Era krisis yang dialami oleh masyarakat Giligenting akhirnya menimbulkan banyak warga mencari cara alternatif untuk menggantikan situasi. Pada tahun 1990, kalangan laki-laki yang berada di Giligenting bermigrasi ke beberapa kawasan perkotaan, seperti Jakarta, Surabaya, Tegal, Semarang, Samarinda, Pontianak, Kalibaru, Serang, dan kota lainnya. Pada masa itu, Pulau Giligenting dikenal sebagai Pulau Putri, sebab kondisi pulau yang banyak dihuni oleh kalangan istri atau ibu-ibu yang ditinggal suaminya merantau. Pada tahun 1993-1995, perilaku merantau tersebut dirasa bisa menjawab kondisi ekonomi, akhirnya para kalangan laki-laki tidak lagi merantau sendiri, mereka membawa istrinya. Hasil merantau atau migrasi kemudian dibuat untuk merenovasi rumah dan mengembangkan modal kembali untuk anakanaknya yang lulus SMP. Pola ini terus berlanjut hingga saat ini tahun 2019. Bahkan, prinsip orang Giligenting saat ini adalah mereka boleh saja menetap di wilayah perkotaan, tetapi tidak meninggalkan kebiasaan dan nilai-nilai kampung halamannya. Hal ini dibuktikan dengan banyaknya warga Giligenting yang pulang kampung saat bulan puasa dan lebaran untuk bertemu dengan orang tua maupun sanak saudara dan keluarganya yang selama ini ditinggalkan ke perkotaan.

Informasi di atas menunjukkan bahwa secara sosio-historis, merantau adalah salah satu strategi hidup masyarakat Pulau Giligenting ketika terjadi hal buruk pada mata pencaharian utama mereka. Kegiatan merantau sudah menjadi budaya turunan dari budaya melayar yang telah bertahuntahun dilakukan oleh warga Kepulauan Giligenting sehingga jika saat ini hampir $80 \%$ dari keseluruhan total jumlah penduduk Giligenting lebih memilih merantau karena kondisi Pulau Giligenting yang semakin hari semakin menunjukan hal buruk, seperti masalah air, hingga hasil laut yang tidak menentu karena keberadaan perusahaan semakin membuat masyarakat Giligenting berbondong- 
bondong untuk pergi mencari mata pencaharian baru di kota-kota besar.

\section{Modalitas dalam Strategi Penghidupan Masyarakat Giligenting}

Strategi penghidupan yang dilakukan oleh masyarakat Giligenting adalah menyesuaikan dengan kondisi lingkungan. Kondisi seperti ini membuat warga Kepulauan Giligenting memanfaatkan berbagai modal untuk dapat bertahan hidup di Kepulauan Giligenting, di antaranya dengan memanfaatkan modal alam. Modal alam di sini adalah keseluruhan potensi alam yang dimiliki oleh masyarakat Giligenting. Ketika terjadi hal buruk dalam mata pencaharian utama mereka, masyarakat Giligenting akan memanfaatkan potensi alam mereka sebagai alternatif penghasilan mereka. Potensi alam Pulau Giligenting yang dipenuhi dengan keindahan pesisir pantainya menjadi daya tarik tersendiri bagi masyarakat luar. Inilah yang kemudian dimanfaatkan oleh masyarakat Pulau Giligenting, yaitu dengan membuka daerahnya sebagai kawasan pariwisata. Pantai Sembilan, Pantai Pasir Putih, Pantai Kahuripan, dan Pantai Sorok adalah pantai-pantai yang berhasil dikembangkan oleh masyarakat sebagai pantai wisata di Pulau Giligenting. Akan tetapi, di balik kesuksesan pengembangan wisata tersebut, masih terdapat masalah dalam pelaksanaannya, yaitu banyaknya kalangan kiai yang menganggap bahwa keberadaan wisata akan membawa kemaksiatan. Tetapi dengan adanya mediasi oleh pemerintah desa, wisata pantai tersebut dapat tetap berjalan dengan kesepakatan bahwa pihak pengelola akan melarang wisatawan yang menggunakan pakaian bikini. Bahkan, di beberapa tempat telah diberi imbauan agar tidak menggunakan baju bikini.

Untuk mengembangkan wisata pantai tersebut, masyarakatlokaljugamenggunakan modal sosialnya. Modal sosial ini berupa jaringan sosial yang dimanfaatkan oleh masyarakat Giligenting untuk mengangkat kegiatan pariwisatanya. Ini terlihat ketika mereka mendatangkan investor-investor lokal untuk bersama-sama mengembangkan pariwisata di Pulau Giligenting sehingga secara tidak langsung mereka juga sedang memanfaatkan modal ekonominya, tetapi modal ekonomi mereka didapat dari penggunaan modal sosial. Inilah yang dimaksud Scoones (2009) bahwa sering kali individu atau kelompok menggunakan strategi penghidupannya dengan mengkombinasikan modal sosial dan modal ekonomi. Hal ini terjadi karena penggunaan satu modal pasti berhubungan dengan penggunakan modal-modal lainnya. Oleh karena itu, kombinasi modal-modal ini menjadi sangat berpengaruh sebagai upaya untuk bertahan hidup.

\section{PEMANFAATAN LIMA KOMPONEN MODAL UNTUK STRATEGI PENGHIDUPAN}

\section{Identifikasi Modal Manusia}

MasyarakatPulau Giligenting memiliki banyak potensi yang dapat membantu kesejahteraan masyarakat sekitar. Potensi modal manusia yang dimiliki masyarakat Giligenting berupa keterampilan dalam mengolah makanan lokal, seperti produk gula siwalan, kue bapel, petis madura, dan abon ikan tuna. Ketiga produk ini sebenarnya mempunyai potensi besar untuk dijual di pasaran karena hasil penelitian menunjukan bahwa permintaan atas gula siwalan terbilang sangat banyak, yaitu sekitar satu ton dalam satu bulan, tetapi karena minimnya minat masyarakat untuk mengembangkan produk tersebut, masyarakat tidak mampu memenuhi permintaan pasar, padahal produk-produk tersebut telah dibantu secara serius oleh pemerintah daerah setempat melalui Badan Usaha Milik Desa (BUMDes). Selain itu, kue bapel juga memiliki permintaan yang tinggi. Dalam satu hari rata-rata penjual bapel dapat menjual sekitar $50-70$ bungkus kue bapel. Hal ini masih ditunjang permintaan di bulan-bulan tertentu, seperti pada bulan Syawal, Muharram, dan Dhulhijjah. Permintaan bapel pada bulan-bulan tersebut naik hingga 3 kali lipat karena banyak masyarakat perantau yang mudik dan kemudian kembali dengan membawa oleh-oleh produk makanan tersebut.

\section{Identifikasi Modal Alam}

Selain potensi skill dalam mengolah produk makanan, seperti diuraikan sebelumnya, potensi keindahan alam merupakan potensi yang memiliki daya pikat tersendiri sebagai modal alam masyarakat Giligenting. Masyarakat sendiri juga telah memanfaatkan potensi tersebut sebagai sebuah strategi alternatif penghidupan mereka, hanya saja kelembagaannya belum teratur. Oleh karena itu, keterlibatan masyarakat dan peran aktif pemerintah sangat diperlukan agar pariwisata dapat dilaksanakan secara keberlanjutan. Hal ini menjadi penting karena pengembangan pariwisata berkelanjutan harus didasarkan pada perlindungan dan peningkatan peluang untuk masa depan, dan pemerintah adalah stakeholder yang mempunyai 
peran besar dalam mewujudkan hal tersebut. Hal ini dianggap mengarah kepada pembatasan pengelolaan semua sumber daya sehingga kebutuhan ekonomi, sosial, dan estetika dapat dipenuhi dengan tetap mempertahankan integrasi budaya, proses esensial ekologis, keanekaragaman hayati, dan sistem pendukung kehidupan. Untuk itu, potensi pariwisata ini seharusnya bisa dijadikan salah satu modal untuk pemberdayaan masyarakat.

Penggunaan konsep Community Based Tourism (CBT) membantu mengarahkan kegiatan pariwisata di Pulau Giligenting menjadi pariwisata berbasis komunitas. "Komunitas" tersebut secara sukarela didorong untuk memahami ruang-ruang pariwisata, dan selanjutnya pengunjung dapat berinteraksi dengan masyarakat lokal untuk sebuah pengalaman pariwisata. Hanya dengan pendekatan CBT ini manfaat pariwisata dapat dirasakan oleh masyarakat, yaitu melalui sebuah program pengembangan masyarakat, pengembangan kapasitas, kontrol lokal, dan pengembangan perusahaan lokal, mata pencaharian berkelanjutan dan pengentasan kemiskinan di lingkungan pariwisata (Dangi \& Jamal, 2016). Oleh karena itu, peran stakeholder dalam menekan berbagai kepentingan sangat penting agar manfaat pariwisata dapat dirasakan secara maksimal oleh masyarakat. Kombinasi antara pengelolaan pariwisata dan pengembangan produk lokal menjadi potensi yang sangat besar jika dijalankan secara maksimal. Keberhasilan kegiatan pariwisata juga dapat menunjang pemasaran bagi produk lokal, begitu pula sebaliknya. Dengan demikian, keberhasilan ini diharapkan dapat menekan angka migrasi di Pulau Giligenting karena adanya penghasilan masyarakat lokal yang meningkat dan opsi diversifikasi mata pencaharian di Pulau Giligenting menjadi bertambah.

\section{Identifikasi Modal Sosial}

Potensi selanjutnya yang tidak kalah penting adalah modal sosial yang berupa jaringan sosial masyarakat Giligenting dengan masyarakat yang bermigrasi ke kota-kota besar. Bagaimanapun juga, masyarakat yang bermigrasi merupakan potensi kuat yang dapat diandalkan oleh masyarakat Giligenting sebagai target pemasaran produk makanan maupun wisata. Banyaknya masyarakat Giligenting yang tersebar di berbagai daerah dapat memudahkan untuk promosi potensi lokal. Sebagaimana yang telah dilakukan oleh beberapa pelaku usaha bapel, mereka menjadikan penduduk migrasi sebagai target pasar utama mereka sehingga produk mereka dapat dikenal di beberapa daerah. Hal ini seharusnya juga berlaku untuk promosi produk makanan lainnya dan produk-produk pariwisata.

Hal tersebut nampaknya mempraktikkan model modal sosial dari Fukuyama (1995). Dia melihat modal sosial sebagai kemampuan yang muncul dari prevalensi kepercayaan dalam masyarakat atau bagian tertentu dari itu. Dia memperlihatkan peran kepercayaan dalam kinerja ekonomi. Meskipun faktor teknologi, pasar, dan modal manusia berkontribusi pada pertumbuhan ekonomi, Fukuyama (1995) menyimpulkan bahwa bahan utama dalam menghasilkan pertumbuhan adalah modal sosial yang menghubungkan budaya kepercayaan, atau, seperti yang disebutkan sebagai "spontaneous sociability" (Ferragina \& Arrigoni, 2017; Fukuyama, 2001; Jackman \& Miller, 1998). Jaringan sosial antara masyarakat Giligenting dengan penduduk migran di daerah merupakan jaringan yang sangat kuat. Rata-rata mereka merupakan anggota keluarga yang memiliki hubungan darah sehinggatingkatkepercayaan antar mereka sangat kuat. Hal ini dapat dijadikan potensi pasar bagi produk lokal yang dapat membantu mendongkrak perekonomian kepulauan.

\section{Identifikasi Modal Ekonomi}

Pada modal ekonomi, masyarakat Giligenting memiliki potensi dengan adanya pemanfaatan uang remitansi. Dengan adanya perputaran uang tersebut, masyarakat Giligenting seharusnya dapat mengembangkan banyak usaha lokal. Selama ini penggunaan uang remitan masih bersifat konsumtif. Oleh karena itu, perlu adanya pembinaan penggunaan uang remitan untuk kegiatan produktif. Dalam hal ini, peran pemerintah setempat menjadi penting sebagai salah satu pengatur pengembangan usaha lokal. Pembinaan pemberdayaan masyarakat lokal dalam memanfaatkan uang remitan perlu diadakan sebagai bentuk upaya peningkatan produktivitas ekonomi lokal. Hal ini dikarenakan jumlah uang beredar di masyarakat merupakan potensi modal ekonomi yang dapat dimanfaatkan sebagai perputaran roda ekonomi daerah. Dengan demikian, pertumbuhan ekonomi daerah dapat berjalan dengan maksimal.

\section{Identifikasi Modal Fisik}

Pada modal fisik, masyarakat Giligenting memanfaatkan potensi laut. Mereka yang menetap di pulau tersebut mempunyai rutinitas memancing, 
mencari cumi-cumi, kerang, dan bekerja di bidang jasa transportasi laut. Masyarakat Giligenting menyeberang dari Pulau Giligenting ke Pulau Madura setiap hari sehingga Pulau Giligenting memliki dua pelabuhan yang terletak di Desa Aenganyar dan Desa Beringsang. Aktivitas pelabuhan ini dimulai pukul 06.00-17.00 WIB. Pelabuhan ini digunakan untuk mengirimkan barang-barang kebutuhan pokok masyarakat Giligenting, tranportasi bagi guru, polisi, warga setempat, dan antar jemput wisatawan ke Pantai Sembilan. Dalam hal penanganan air bersih, masyarakat Giligenting menggunakan air sumur. Kualitas air sumur dipengaruhi oleh letak rumah. Air sumur yang terletak dekat dengan pantai maka airnya sedikit asin, sedangkan air sumur yang letaknya jauh dari pantai memiliki kualitas air yang cukup bagus untuk dikonsumsi rumah tangga. Mengenai akses informasi, pulau ini terdapat listrik PLN dan tower Telkomsel sehingga masyarakat dapat menyesuaikan perkembangan teknologi.

\section{PENUTUP}

Potensi lokal yang dapat dioptimalkan di Pulau Giligenting dapat dibedakan menjadi dua, yaitu potensi alam dan potensi sumber daya manusia. Wilayah Giligenting memang kurang produktif untuk usaha pertanian karena hanya memungkinkan untuk ditanami palawija yang dipanen setahun sekali. Usaha pertanian tidak lebih dari bentuk aktivitas mengisi waktu luang sebab kebutuhan subsisten masyarakat banyak dicukupi oleh kiriman keluarga di perantauan. Sebaliknya, wilayah laut sekitar Giligenting sangat berpotensi untuk aktivitas penangkapan ikan dan budi daya rumput laut. Sayangnya usaha ini masih dilakukan secara tradisional dan berorientasi subsisten sehingga hasil yang didapatkan tidak mampu menggerakkan perekonomian secara masif. Sebenarnya Pulau Giligenting bisa dikembangkan menjadi wisata bahari yang dikelola dengan konsep Community Based Tourisme. Di pulau ini hanya Desa Bringsang yang dapat menginisiasi pengelolaan potensi alam menjadi destinasi wisata bernama Pantai Sembilan. Hal ini tidak lepas dari keberadaan elite lokal yang mampu menjalin jejaring dengan stakeholders dari luar Giligenting serta mampu memobilisasi masyarakat untuk mendukung kewirausahaan sosial. Jika setiap elite di Giligenting mampu menggerakkan sumber daya manusia dan mengolah sumber daya alam untuk kemajuan Pulau Giligenting, bukan tidak mungkin pulau ini menjadi tumpuan ekonomi masyarakat lokal selain uang remitan dari perantauan.
Permasalahan utama yang dihadapi masyarakat Giligenting adalah terbatasnya sumber daya manusia usia produktif yang menetap di Pulau Giligenting dan mampu menginisiasi pemberdayaan masyarakat berdasarkan potensi lokal. Kebanyakan penduduk usia produktif pergi ke perantauan untuk meningkatkan kesejahteraan keluarganya. Pertimbangan efisiensi dan efektifitas membuat mereka memilih menjadi pemilik warung di Jakarta daripada mengolah sumber daya alam di Pulau Giligenting. Migrasi besar-besaran ini mengakibatkan Pulau Giligenting dihuni oleh lansia dan anak-anak. Kendatipun ada penduduk usia produktif yang menetap, hanya sedikit dari mereka yang mampu memprakarsai kegiatan pemberdayaan masyarakat.

Strategi penghidupan masyarakat pesisir tidak dapat dilepaskan dari konteks sosio-historis. Individu maupun kelompok pada kenyataannya mempelajari strategi penghidupan dari proses sejarah yang amat panjang. Namun, dalam perjalanannya, hal tersebut sudah tidak menjadi strategi satu-satunya karena seiring dengan perkembangannya, mulai muncul potensi-potensi baru yang dapat dijadikan sebagai opsi strategi penghidupan masyarakat pesisir. Dari kasus masyarakatPulau Giligenting, kita dapatmengetahui bahwa strategi penghidupan masyarakat yang sudah dilakukan sejak lama, yaitu migrasi, dapat menjadi sebuah masalah baru. Migrasi yang sudah dipercaya sebagai solusi dari kebuntuan ekonomi, jika diteruskan akan menjadi bumerang bagi lingkungan sekitar karena tingginya tingkat migrasi yang berakibat pada rendahnya penduduk usia produktif di Pulau Giligenting. Hal ini kemudian menyebabkan tidak maksimalnya pemanfaatan potensi lokal, padahal Pulau Giligenting memiliki potensi pariwisata yang amat menjanjikan terhadap keberlangsungan hidup masyarakat Giligenting. Jika potensi wisata dan produk lokal dikelola, dikembangkan, dan dimanfaatkan dengan baik dengan mengembangkan modal sosial dan ekonomi, dapat berpotensi meningkatkan kesejahteraan masyarakat Pulau Giligenting sekaligus menekan angka migrasi. Oleh karena itu, penulis menyimpulkan bahwa bentuk-bentuk strategi penghidupan yang ditemukan di Pulau Giligenting ditentukan oleh potensi lokal dan permasalahan faktual yang dialami penduduk.

\section{UCAPAN TERIMA KASIH}

Penulis mengucapkan terima kasih kepada Badan Penelitian dan Pengembangan Masyarakat 
(BPPM), Fakultas IImu Sosial dan IImu Politik, Universitas Brawijaya yang telah membiayai keseluruhan penelitian ini. Peneliti juga berterima kasih kepada pemerintah, tokoh, dan pejabat lokal Pulau Giligenting yang telah memberi kemudahan akses penelitian.

\section{PERNYATAAN KONTRIBUSI PENULIS}

Artikel ini ditulis oleh Nyimas Nadya Izana sebagai Kontributor Utama dan Anik Susanti sebagai Kontributor Anggota. Menimbang hal tersebut, penulis juga telah melampirkan surat pernyataan kontribusi penulis yang ditandatangani oleh kedua penulis.

\section{DAFTAR PUSTAKA}

Ahlburg, D. A. (1991). Remittances and their impact: A study of Tinga and Western Samoa. National Centre for Development Studies.

Ambari, M. (2018). Negara tidak hadir di tengah masyarakat pesisir? Mongabay. https://www. mongabay.co.id/2018/04/20/negara-tidak-hadirdi-tengah-masyarakat-pesisir/

Aparicio, J., Tenza-Abril, A. J., Borg, M., Galea, J., \& Candela, L. (2019). Agricultural irrigation of vine crops from desalinated and brackish groundwater under an economic perspective: A case study in Siǵgiewi, Malta. Science of the Total Environment, 650, 734-740. https://doi. org/10.1016/j.scitotenv.2018.09.059

Attard, G., \& Azzopardi, E. (2005). An overview of irrigation system performance on the island of Malta. Options Méditerranéennes. Série B: Etudes et Recherches (CIHEAM), 165-172.

Branda-Shute, R., \& G. Brana-Shute. (1982). The magnitude and impact of remittances in the Eastern Caribbean: a research note (W. F. Stin). Research Institute on Immigration and Ethnic Studies, The Smithsonian Institute.

Carloni, A., \& Crowley, E. (2005). Rapid guide for missions: Analysing local institutions and livelihoods. Food and Agriculture Organization of the United Nations.

Chambers, R. (1995). Poverty and livelihoods: whose reality counts? ID discussion paper. IDS.

Connell, J., \& Conway, D. (2000). Migration and remittances in Island Microstates: A comparative perspective on the South Pacific and the Caribbean. International Journal of Urban and Regional Research, 24(1), 52-78. https://doi.org/ https://doi.org/10.1111/1468-2427.00235
Dangi, T. B., \& Jamal, T. (2016). An integrated approach to "sustainable community-based tourism." Sustainability (Switzerland), 8(5). https://doi.org/10.3390/ su8050475

Fang, Y. P., Fan, J., Shen, M. Y., \& Song, M. Q. (2014). Sensitivity of livelihood strategy to livelihood capital in mountain areas: Empirical analysis based on different settlements in the upper reaches of the Minjiang River, China. Ecological Indicators, 38, 225-235. https://doi.org/10.1016/j. ecolind.2013.11.007

Ferragina, E., \& Arrigoni, A. (2017). The Rise and fall of social capital: Requiem for a theory? Political Studies Review, 15(3), 355-367. https://doi. org/10.1177/1478929915623968

Fukuyama, F. (1995). Trust: The social virtues and the creation of prosperity. The Free Press.

Fukuyama, F. (2001). Social capital, civil society and development. Third World Quarterly, 22(1), 7-20. https://doi.org/10.1080/713701144

Giesbrecht, D. J. (2011). Small-scale fisher livelihood strategies and the role of credit in Paraty Brazil. University of Manitoba.

Huda, M., \& Yunas, N. S. (2017). Good extractive governance sebuah gagasan untuk kesejahteraan masyarakat wilayah pertambangan di Indonesia. Jurnal Matra Pembaruan, 1(2), 75-84. https://doi.org/10.21787/ mp.3.2.2019.99-108

Islam, F. S., Pratomo, D. G., \& Khomsin, K. (2019). Identification of coral reef conditions using hydro-acoustic technology in Giligenting Island, Sumenep Regency Indonesia. IPTEK Journal of Proceedings Series, 2, 40. https://doi. org/10.12962/j23546026.y2019i2.5303

Jackman, R. W., \& Miller, R. A. (1998). Social Capital and Politics. Annual Review of Political Science, 1(1), 47-73. https://doi.org/10.1146/annurev. polisci.1.1.47

Maloeng, L. J. (2018). Metodologi Pendekatan Kualitatif. PT Remaja Rosdakarya.

Mandle, J. (1996). Persistent underdevelopment, change and economic modernization in the West Indies. Gordon and Breach.

Marshal, D. I. (1984). Migration and development in the eastern Caribbean (R. A. Pasto (ed.); Migration). Westview Press.

Mbaiwa, J. E. (2011). Changes on traditional livelihood activities and lifestyles caused by tourism development in the Okavango Delta, Botswana. Tourism Management, 32(5), 1050-1060. https:// doi.org/10.1016/j.tourman.2010.09.002 
Papadimitriou, L., D’Agostino, D., Borg, M., Hallett, S., Sakrabani, R., Thompson, A., \& Knox, J. (2019). Developing a water strategy for sustainable irrigated agriculture in Mediterranean island communities - Insights from Malta. Outlook on Agriculture, 48(2), 143-151. https://doi. org/10.1177/0030727019841060

Purba, D. (2016). Rancangan model CSR (Pertiwi) sebagai basis pengembangan kearifan lokal masyarakat Pulau Giligenting. National Conference On Economic Education, 315-350.

Putri, M. R., Setiawan, A., Pohlmann, T., Mayer, B., \& Gade, M. (2016). The assessment of oil pollution in Seribu Islands based on remote sensing and numerical models. European Space Agency, (Special Publication) ESA SP, SP-740(May).

Robert, L., Cremona, M., \& Knox, G. (2015). Why Malta's national water plan requires an analytical policy framework. The Today Public Policy Institut.

Rubenstein, H. (1983). Remittances and rural underdevelopment in the English-Speaking Caribbean. Human Organization, 42(4), 295-306. https://doi. org/10.17730/humo.42.4.0709108414538471

Salafsky, N., \& Wollenberg, E. (2000). Linking livelihoods and conservation: A conceptual framework and scale for assessing the integration of human needs and biodiversity. World Development, 28(8), 1421-1438. https://doi.org/10.1016/ S0305-750X(00)00031-0

Satria, A. (2015). Pengantar Sosiologi Masyarakat Pesisir. Obor.

Scoones, I. (1998). Sustainable rural livelihoods a framework for analysis. In IDS Working Paper (Vol. 72, Issue 2). https://doi.org/10.1057/ palgrave.development. 1110037

Scoones, I. (2009). Livelihoods perspectives and rural development. Journal of Peasant Studies, 36(1), 171-196. https://doi. org/10.1080/03066150902820503

Susanto, V. Y. (2019, September 12). Hingga Agustus 2019, KKP salurkan asuransi nelayan sebanyak Rp 388 miliar. Kontan.Co.Id. https://nasional. kontan.co.id/news/hingga-agustus-2019-kkp-salurkan-asuransi-nelayan-sebanyak-rp-388-miliar

Syamsuddin, M. (2019). History of Madura: Sejarah, Budaya dan Ajaran Luhur Masyarakat Madura. Araska.

Tittonell, P., Muriuki, A., Shepherd, K. D., Mugendi, D., Kaizzi, K. C., Okeyo, J., Verchot, L., Coe, R., \& Vanlauwe, B. (2010). The diversity of rural livelihoods and their influence on soil fertility in agricultural systems of East Africa - A typology of smallholder farms. Agricultural Systems,
103(2), $\quad$ 83-97. https://doi.org/10.1016/j. agsy.2009.10.001

van den Berg, M. (2010). Household income strategies and natural disasters: Dynamic livelihoods in rural Nicaragua. Ecological Economics, 69(3), 592-602. https://doi.org/10.1016/j.ecolecon.2009.09.006

van Holt, T. (2012). Landscape influences on fisher success: Adaptation strategies in closed and open access fisheries in southern Chile. Ecology and Society, 17(1). https://doi.org/10.5751/ ES-04608-170128

Viola, F., Sapiano, M., Schembri, M., Brincat, C., Lopez, A., Toscano, A., Diamadopoulos, E., Charalambous, B., Molle, B., Zoumadakis, M., Armengol, A. T., Vich, M. G., \& Noto, M. T. (2014). The state of water resources in major Mediterranean islands. Water Resources, 41(6), 639-648. https://doi. org/10.1134/S0097807814060207

Wright, J. H., Hill, N. A. O., Roe, D., Rowcliffe, J. M., Kümpel, N. F., Day, M., Booker, F., \& MilnerGulland, E. J. (2016). Reframing the concept of alternative livelihoods. Conservation Biology, 30(1), 7-13. https://doi.org/10.1111/cobi.12607

Zamzami, L. (2011). Pemberdayaan ekonomi masyarakat pesisir di Nagari Ampiang Perak, Sumatera Barat. MIMBAR, XXVII(1), 113-125. https://doi. org/https://doi.org/10.29313/mimbar.v27i1.318

Zenteno, M., Zuidema, P. A., de Jong, W., \& Boot, R. G. A. (2013). Livelihood strategies and forest dependence: New insights from Bolivian forest communities. Forest Policy and Economics, 26, 12-21. https://doi.org/10.1016/j. forpol.2012.09.011 